\title{
The Role of Intrapreneurship on the Growth of Iron and Steel Manufacturing Companies in Bulawayo,
} Zimbabwe

\author{
Alex Madzikova, Gwendoline Vusumuzi Nani \\ Graduate School of Business, National University of Science and Technology (NUST), Zimbabwe \\ alex.madzikova@gmail.com,gwendoline.nani@nust.ac.zw/gweni.nani@gmail.com
}

\begin{abstract}
This study sought to find out the role of intrapreneurship on the growth of iron and steel manufacturing companies in Bulawayo, Zimbabwe. A post-positivist paradigm, a mixed method approach and a cross sectional design were adopted for the investigation. Three hundred and fifteen (315) middle management and supervisory staff drawn from twenty-two (22) iron and steel manufacturing companies in Bulawayo participated. Multiple stratified random sampling and heterogeneous purposive sampling were used to choose two hundred (200) respondents for the quantitative study and eight participants for the qualitative study respectively. Questionnaires and in-depth interviews were the data collecting instruments for quantitative and qualitative data respectively. Quantitative data was analysed using descriptive and inferential statistics and qualitative data was thematically analysed. Findings revealed that innovativeness, proactiveness, and risk taking were the key dimensions of intrapreneurship. Both quantitative and qualitative analyses showed the prominent measures of company growth in the iron and steel manufacturing companies as financial, employee numbers, productivity, and product range. Statistically intrapreneurship was found to be correlated to the growth of the iron and steel manufacturing companies. The study drew the following conclusions. Firstly, intrapreneurship is not a preferred strategy for driving growth in the iron and steel manufacturing companies in Bulawayo. Secondly, financial and product range were identified as the key measures of company growth. Thirdly, company support for intrapreneurship and individual's intrapreneurial disposition were statistically linked to company growth. The study recommended that companies should motivate and support employees' innovativeness, proactiveness, and risk taking through ideas, actions and work. Measurement of company growth should be expanded to include qualitative measures.
\end{abstract}

Keywords: Company growth, intrapreneurship, iron, steel manufacturing.

\section{Introduction}

Zimbabwe, once boasted of a diversified manufacturing sector made up of specialised sub-sectors. These included the manufacturers of foodstuffs, beverages, drugs, clothing, building materials, wood and furniture, chemicals, metal and metal products, leather and household products, plastics and packaging materials (Confederation of Zimbabwe Industries (CZI), 2018). The metal and metal products manufacturing subsector included aluminium, copper, iron, steel and other metal manufacturers (Zimbabwe Economic Policy Analysis and Research Unit (ZEPARU), 2014). However, for a decade, the manufacturing sector in Zimbabwe recorded below 50\% capacity utilisation levels [Confederation of Zimbabwe Industries, (CZI) (2009-2018). The once highly industrialised Zimbabwean economy, second only to South Africa, declined into an informal economy (Mlambo, 2017; Dube, 2011; Stoneman, 1990). Drastic policy shifts, high costs of production, foreign currency shortages, lack of concessionary funding, aged equipment, competition from cheap imports were some of the factors blamed for the poor performance of the manufacturing sector in Zimbabwe [CZI, 2018].

Bulawayo, which was once the industrial hub of Zimbabwe, suffered the most serious deindustrialisation as companies closed at a faster rate than other cities and towns [Mbira, 2015]. According to Deloitte (2017), globally, the iron and steel making industry was one of the most technologically advanced industries. Gonzalez \& Kaminski (2011) assert that the iron and steel industry is very complex and is intrinsically linked with the world economy at large. Steel consumption is a key indicator of national development, which motivated global manufacturing giants to maintain a continuous interest in the steel industry (Singal, 2018; Pal, 2013). Gonzalez \& Kaminski (2011) further state that steel products are needed by many industries, such as automotive, construction, and other manufacturing sectors. The Zimbabwe Economic Policy Analysis Research Unit (ZEPARU) (2014) pointed out that various types of steel are used in infrastructural construction as the core structure, reinforcement or as accessories. 
According to Matinde (2014), steel is also used as a raw material in the manufacture of finished products like automobiles, appliances, tools, tubular products, beams, bars and sheets. The Government of Zimbabwe's Transitional Stabilisation Programme (TSP), also projected that Zimbabwe's iron and steel companies had potential to earn US $\$ 1$ billion from exports, enough to offset the import bill of US\$350 million (Ministry of Finance, 2018). Previously, through Zimbabwe Agenda for Sustainable Socio-Economic Transformation (ZIMASSET) Blueprint, the Government of Zimbabwe had also pinned the growth of the manufacturing sector on the revival of the iron and steel sector (Ministry of Finance, 2013). Notwithstanding the global surplus in iron and steel output, Zimbabwe like other developing resource rich countries, realised the need to shift from being an exporter of raw metal ores to an exporter of fully beneficiated finished products. ZEPARU (2014) established that in Zimbabwe and for the period 2009 to 2011, the contribution of iron and steel manufacturing to the engineering and metals gross output was poor (less than 5\%). However, the iron and steel subsector had potential to become the mainstay of the engineering and metals sector. The Government of Zimbabwe planned to set up new iron and steel companies (Zimbabwe Agenda for Sustainable SocioEconomic Transformation (ZIMASSET), 2013). Furthermore, the Government of Zimbabwe prioritised resuscitation and expansion of struggling existing iron and steel plants (Transitional Stabilisation Plan (TSP), 2018). The motivation for these various attempts to develop the iron and steel sector was pinned on a desire to benefit from the country's estimated 30-billion-ton ore reserves (ZEPARU, 2014).

ZEPARU (2014) noted that innovation and technology adoption were inevitable for development of Zimbabwe's iron and steel sector. Enhanced technologies, economies of scale and new innovations needed to be considered in iron and steel operations [ZEPARU, 2014]. The Government of Zimbabwe has in time past rolled out bailout initiatives and introduced policy interventions to prop up struggling manufacturing companies. Notable examples of the yesteryear bailout initiatives were the US\$70 million Zimbabwe Economic Trade Revival Facility (ZETREF) launched in 2010 (Mudarikiri, 2012) and the US\$40 million Distressed Industries and Marginalised Areas Fund (DIMAF) launched in 2011 (Samukange, 2015). On policy interventions, the government introduced import substitution and export promotion Statutory Instruments (Control of Goods (Open General Import Licence) (No.2) (Amendment Notice No.8), 2016; Control of Goods (Open General Import Licence) (Amendment Notice, No.5), 2017). The performance of Bulawayo manufacturing companies improved after each government intervention, but the high-performance level could not be sustained. Matinde (2014) opined that iron and steel companies in Zimbabwe were not growing due to a lack of long term strategies that focused on value addition of local iron and steel products. Prior to this study, intrapreneurship had been scantily studied in developing countries. It was particularly interesting to note that published studies on intrapreneurship in Africa were few. This showed slow permeation of the concept into the continent. Therefore, this study sought to establish if intrapreneurship, as a long term strategy, played a key role on the growth of iron and steel manufacturing companies in Bulawayo, Zimbabwe. This study was guided by the following primary and secondary research objectives.

Primary Objective: The primary objective of the study was to find out the role of intrapreneurship on the growth of iron and steel manufacturing companies in Bulawayo, Zimbabwe.

Secondary Objectives: The primary objective was supported by the following secondary objectives.

- To identify key dimensions of intrapreneurship.

- To identify key measures of company growth.

- To find out if there is a significant relationship between intrapreneurship and the growth of iron and steel manufacturing companies in Bulawayo, Zimbabwe.

- To find out the extent to which intrapreneurship contributes to the growth of iron and steel manufacturing companies in Bulawayo, Zimbabwe.

\section{Literature Review}

According to Deloitte (2015), the implementation of business ideas or solutions to problems within an existing business entity is called intrapreneurship. In general, intrapreneurship is defined as entrepreneurship practised within existing companies (Azami, 2014; Nicolaidis \& Kosta, 2011; Stefanovici, 2012; Antoncic \& Hisrich, 2003). A more comprehensive definition is that: Intrapreneurship represents the initiation and implementation of innovative systems and practices within an organisation, by some of its staff 
under the supervision of a manager who takes the role of an intrapreneur, in order to improve the economic performance of the organisation, by using a part of its resources, namely those that previously have not been used in an appropriate manner (Maier \& Zenovia, 2011). Intrapreneurship has also been severally defined as a portfolio of innovation strategies within an existing organisation or emergent behavior divorced from customary ways (Zhao, 2013; Nicolaidis \& Kosta, 2011; Antoncic \& Hisrich, 2003). According to de Jong \& Wennekers (2008), intrapreneurship refers to employee initiatives in organisations to undertake something new for the business, without being asked to do so. Intrapreneurship embraces the "freedom to fail" and enable the partakers to be adventurous (Buekens, 2014). The focus of intrapreneurship is on innovation and risky activities (Azami, 2013). Intrapreneurship is motivated by challenges and accomplishment while risk is moderated by being shared with the employing company (Birkemalm \& Jansson, 2018).

Theoretical Framework: Historically, entrepreneurship is credited with reshaping the business world through implementing new business ideas within the existing business entity or by starting a new venture (Maier \& Zenovia, 2011). However, intrapreneurship, a growing and evolving concept, is taking over credit for business initiatives done within existing business entities (Birkemalm \& Jansson, 2018). Intrapreneurship is an offshoot of entrepreneurship and at the same time falls within the domain of employee behaviour (de Jong \& Wennekers, 2008). One of the theories underpinning this study is organisational citizen behaviour (OCB). OCB relates to individual, discretionary actions by employees that are outside their formal job requirements (Pickford \& Joy, 2016). This theory advocates that employees with organisational citizenship are self-motivated, forward thinking and go beyond their normal job functions. This extra mile approach helps companies grow.

Conceptual Framework: Various dimensions of intrapreneurship and various measures of company growth were identified in literature. Various dimensions of intrapreneurship proposed by various scholars include: (1) innovativeness; (2) proactiveness; (3) self-renewal; (4) new business venturing; (5) risk taking; and (6) competitive aggressiveness. Innovativeness is concerned with continual renewal of products or services or processes or procedures or techniques while proactiveness is concerned with attempts to stay ahead of competition in business aspects (Antoncic \& Hisrich, 2003). Employees' proactive behaviour is a critical determinant of long term organisational success (de Jong \& Wennekers, 2008). Self-renewal is the flexibility to adapt to the environmental changes. This is achieved through strategic reformulation, reorganisation and organisational change (Antoncic \& Hisrich, 2003). New business venturing is the creation of new businesses within the existing organisation (Atheya \& Arora, 2015). Risk taking is premised on the fact that there is disruption of the status quo, which at times is done without top management approval (Jong, Parker, Wennekers, \& Wu, 2011) posing a career risk for the individual intrapreneur. However, Alipour, Idris \& Karimi (2011) contend that all levels across the company including leaders, managers and employees must have a desire to take a risk. Competitive aggressiveness is when a company challenges and competes with its competitors in order to be noticed and dominate (Antoncic \& Hisrich, 2003). Figure 1 shows a conceptual framework, which depicts intrapreneurship dimensions as antecedents to company growth.

Figure 1: Conceptual Framework for the Hypothesized Relationship

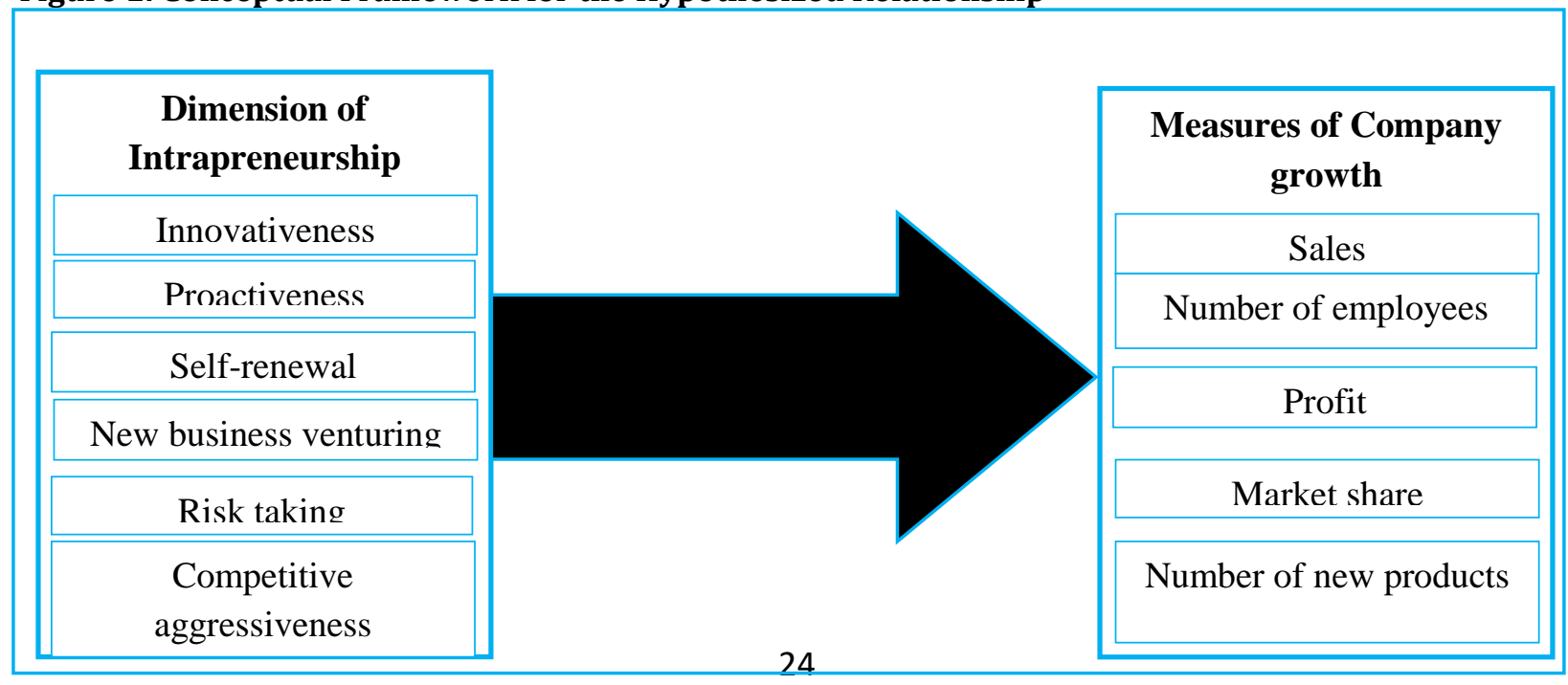


Based on critical analysis of past studies on dimensions of intrapreneurship, innovativeness, risk taking, and proactiveness were selected as the most prominent dimensions. This study sought to test if these identified key dimensions of intrapreneurship had an impact on the growth of iron and steel manufacturing companies in Bulawayo, Zimbabwe.

Factors that Influence Intrapreneurship: Individual, organisational and environmental factors have been identified as major influences to intrapreneurial activity in companies whereby the environmental factors are there to ignite the interaction between the individual and organisational factors (Ogidi, 2014). According to Alipour, Idris \& Karimi (2011), organisational factors that help to create intrapreneurship in companies include: organisational structure; organisational culture; management support; reward and recognition; and resource availability. Organisational structure defines authority levels, span of control, hierarchy, communication channels, decentralization level among other structural issues that affect innovation environment greatly. Organisational culture are values, beliefs, opinions, and behaviours, which should be positive to support intrapreneurship. Management support is at the core of facilitating intrapreneurship by availing adequate resources and ensuring there is buy-in into intrapreneurial initiatives throughout the company. Reward and recognition motivate employees to take risks associated with intrapreneurial behaviours. Resource availability is a function of the quantity of both tangible and intangible resources that influence the company's ability to engage in intrapreneurial activities with the companies having more resources able to take higher risk intrapreneurial adventures (Alipour, Idris \& Karimi, 2011).

Company Growth: According to Gruenwald (2015), business practitioners and academics have differing views on company growth. Business practitioners view company growth as a complex qualitative process of internal development whereas academics view company growth as a simple quantitative attribute. Lee, Brown \& Schlueter (2016) pointed to the existence of different growth episodes, different growth trajectories, and different growth triggers. The differences in growth trajectories led Tajnikar, Ponikvar \& Bonca (2016) to note that there are growing and fast-growing companies. Penrose, cited in Lockett, Wiklund, Davidsson \& Girma (2011), identified organic and acquisitive growth as the two eminent types of company growth. Organic growth is expansion of an existing company by starting new business ventures, driven by the actions of entrepreneurs (later recognized as intrapreneurs). In a study of Dutch companies by Zhou \& de Wit (2009), an integrated analysis of individual, organisational and environmental determinants of company growth revealed that only individual and organisational determinants affect company growth. Similarly, Sarlija, Pfeifer, Jeger \& Bilandzic (2016) argued that there are four determinants of nonlinear, temporal company growth and these are individual, company, organisational and industry or environmental.

Why Measure Company Growth? Company growth is used as a gateway to introducing innovation and technical changes (Garcia-Manjon \& Romero-Marino, 2012). Studies done in France and Italy found that innovative companies grow more than non-innovative companies (Colombelli, Haned \& Le Bas, 2013; Cucculelli \& Ermini, 2012). The importance of correctly measuring company growth is revealed in a study by Gruenwald (2015), which concluded that company growth is a complex phenomenon that cannot be sufficiently explained by a simple linear model. Acquisitive growth is externally driven by actions of management to acquire other existing companies (Lockett et al., 2011). The researcher recruited facilitators at strategic levels in the iron and steel manufacturing companies to improve access and administration of the questionnaires. Before qualitative data was collected, pilot interviews were conducted with three participants. The facilitators were coached on how to draw the respondents in a random, unbiased way by using a raffle system.

The researcher physically delivered and collected the questionnaires to and from some identified facilitators who had direct contact with the individual respondents. There is no universal formula to measure company growth as different companies use different measures. Business practitioners and academics advocate for qualitative and quantitative measures respectively (Gruenwald, 2015). The focus of intrapreneurship is on innovation and risky activities (Azami, 2013). Intrapreneurship is motivated by challenges and accomplishment while risk is moderated by being shared with the employing company (Birkemalm \& Jansson, 2018). Some of the specific and holistic ways of measuring company growth are tracking growth in sales, profits, product range, production capacity, number of employees, and number of stations (Gerald \& 
Elisifa, 2013). From the reviewed studies, the most popular measures of company growth are sales, followed by employment levels.

\section{Methodology and Data Issues}

This study adopted a post-positivist view as a deterministic philosophy in which causes determine the effects (Creswell, 2014). The post-positivist paradigm enabled the researcher to: (1) have the ability to see the whole picture; (2) assume a learning role; (3) value problem setting over problem solving to get good outcomes; (4) be reflexive and not dogmatic or too authoritative; and (5) value dialogue (Ryan, 2006).

Research Approach: The mixed methods approach was used in the study primarily for the purpose of: (1) triangulation; (2) complementarity; (3) development; (4) expansion; and (5) initiation (Ragab \& Arisha, 2018; Cameron, 2015; Saunders, et al., 2016; Teddlie \& Tashakkori, 2006). According to Cameron (2015), the utility of mixed methods is that they: (1) maximise strength while reducing limitations of single methods; (2) are dependent on the research questions; (3) increase research validity; and (4) optimize use of resources.

Research Design: A cross-sectional design which involves the collection of either quantitative or qualitative data or both on more than one case was the preferred design. The cross-sectional design takes a 'snapshot' view of the research problem at a particular point in time by eliciting the perspectives of a number of people (Saunders et al., 2016; Greener, 2008; Sekaran, 2003). Quantitative data was collected on the two main variables of intrapreneurship and company growth and their elements. This study sought to establish if sales, number of employees, number of new products introduced, market share, and profits were recognised measures of company growth in the iron and steel manufacturing companies in Bulawayo, Zimbabwe. The cross sectional design also allowed for the collection of qualitative data. Quantitative and qualitative variables were examined to detect patterns of association (Bryman, Bell, Hirschsohn, Dos Santos, du Toit, Masenge, Van Aardt \& Wagner, 2017).

Population: The population of a study encompasses individuals who hold the information the researcher wishes to obtain in order to address the research question (Ragab \& Arisha, 2018). In this study, the researcher relied on the membership database on the Engineering, Iron and Steel Association of Zimbabwe (EISAZ) website to establish the population of the study. The EISAZ had 136 registered companies in Zimbabwe of which 22 companies were from Bulawayo. The 22 companies in Bulawayo fell into five specialised sub-categories of: (1) billets and shafts, (2) bolts and support systems, (3) machining and fabrication, (4) castables and foundry, and (5) wire drawing, fencing and reinforcements. According to Pindiriri (2018), the 22 registered iron and steel manufacturing companies in Bulawayo had in their employ approximately 315 people in supervisory and middle management positions. The 315 members of supervisory and middle management were the study population. It was therefore imperative that if intrapreneurship existed in the companies, the supervisory and middle management members were at the heart of its processes.

Sampling Frame: The sampling frame is a list of individuals or units, within the population, from which the sample is drawn (Greener, 2008). All the 22 iron and steel manufacturing companies in Bulawayo were part of the sampling frame. The sampling frame was demarcated into five strata of specialised sub-categories identified for the iron and steel manufacturing companies in Bulawayo. The identified five strata were (1) billets and shafts, (2) bolts and support systems, (3) machining and fabrication, (4) castables and foundry, and (5) wire drawing, fencing and reinforcements. The sampling frame was composed of 315 people with different job specifications in their employing companies like Engineer, Accountant, Buyer, Foreman, Human Resources Officer, and Chemist. The study was structured to include people from all departments in the iron and steel manufacturing companies for generalisability of the results.

Sampling Techniques: Non-biased selection of respondents and participants for quantitative and qualitative data collection respectively from all the five sub-categories in the iron and steel manufacturing sector was done. This study employed both probability and non-probability sampling for quantitative and qualitative data collection respectively. According to Saunders et al. (2016), stratified random sampling is chosen on the basis that: (1) the sample should represent the population; (2) the research does not require face-to-face 
contact; (3) the sampling frame contains all relevant strata; and (4) the sampling frame contains no periodic patterns. The number of samples drawn per strata was determined mathematically using ratio calculations to spread the required sample. This was followed by another ratio calculation to spread sample requirements in proportion to the company sizes.

Sample Size: The sizes of samples for quantitative and qualitative data collection differ due to: (1) nature of the data collected; (2) method and tools of data analysis; and (3) required results. Similar to Creswell's (2014) assertion, this study did not deem differing sample sizes for quantitative and qualitative data to be a problem as the two's purposes are generalisation for population and gaining in-depth perspectives respectively. Using Raosoft sample size calculator (2004), at a margin of error (tolerance) of $+/-5 \%$ and confidence level (uncertainty) of $+/-95 \%$, and a population of 315 people, a minimum of 174 respondents were required for the quantitative data collection. At $99 \%$ confidence level and holding all other variables constant, a minimum of 214 respondents were needed. Using the law of averages, the researcher targeted and distributed questionnaires for quantitative data collection to 200 respondents picked from the five identified strata. For the qualitative data collection, purposive sampling was used to pick participants from each identified stratum. Respondents perceived to hold valuable information in each stratum were targeted (Saunders et al., 2016). Three samples were drawn from the machining and fabrication strata as the single largest strata. The castables and foundry stratum also had two participants as the second respondent was a referral. The sample size for the qualitative data collection was eight.

Data Collection: In this study both quantitative and qualitative data were gathered from people in supervisory and middle management positions. The quantitative and qualitative data was collected concurrently (Ragab \& Arisha, 2018; Cameron, 2015; Creswell, 2014; Teddlie \& Tashakkori, 2006). The QUAN and QUAL methods were intended to establish causal relationships and explain relationships respectively at the same time (Teddlie \& Tashakkori, 2006). Respondents and participants were drawn from each of the identified five strata. For quantitative data collection, multiple stratified random sampling was the most appropriate technique for selecting respondents. For collecting qualitative data, heterogeneous purposive sampling was used to pick respondents perceived to hold valuable information in each stratum. Heterogeneous purposive sampling is chosen for the exploratory qualitative study when: (1) the focus is to identify key themes; and (2) there is no need for the sample to proportionally represent the population (Saunders et al., 2016). The quantitative data collection was preceded by a pilot study with ten respondents to check for relevance and any ambiguity.

Methods used to generate new ideas and the attitude towards risk taking by employees portrayed companies that did not want to move away from their traditional ways of improving operations. Would be respondents were also appraised of the reasons for conducting the study and ethical issues surrounding the study were explained. According to Dikko (2016), to achieve study credibility and trustworthiness, pilot testing of the research instrument is done in conditions similar to the actual test conditions. The researcher conducted face-to-face interviews with eight purposively selected participants. The participants were arbitrarily coded using a combination of three letters and two digits. For example, key informant one was designated as ISK01. Interviews of consenting participants were recorded while for others who were not willing to be recorded, notes were taken of their answers. Deeper follow up probing questions were used to seek further clarifications and to motivate the participant to go into deeper thought. This allowed for rich descriptive data in the participants' own words (Taylor, Bogdan \& DeVault, 2016) to be gathered.

Validity: Kothari (2004) summarised validity as the capacity of the instrument to measure something without bias or errors. The validity of the questionnaire was reviewed by a research supervisor for readability, feasibility, clarity, layout, style, and wording. According to Greener (2008), a reliable questionnaire produces auditable, consistent, and repeatable results from different people.

Reliability: The questionnaire's scales were subjected and passed a Cronbach's Alpha test, yielding the value, 0.70 , an indication that the instrument was reliable (Creswell, 2014).

Credibility and Trustworthiness of Qualitative Data: To improve the trustworthiness of the qualitative results, triangulation of the data was achieved by interviewing multiple participants from different strata in 
the iron and steel manufacturing sector and drawing themes after converging the various participants' answers. Member checking, described as taking the final report to the participants to solicit their opinion on the accuracy of the report (Creswell, 2014), was also done. Multiple regressions analysis was employed. The positives of the role played by intrapreneurship on company growth were well articulated by the participants, but a lot of reservations existed on the extent to which free flow of ideas and risk taking were allowed in the iron and steel manufacturing companies in Bulawayo.

\section{Empirical Findings}

Quantitative and qualitative data were presented and analysed separately, before they were combined to yield the overall analysis. As directed by Sekaran (2003), user friendly and interactive software programs were used for data analysis. Empirical findings were arranged according to objectives and presented separately for quantitative and qualitative data.

Quantitative Data Presentation and Analysis: Quantitative data collected using questionnaires was analysed using the Statistical Package for Social Sciences (SPSS) 16.0 package. For the testing of the significance of the relationship between intrapreneurship and company growth, Pearson's correlation was used. For checking the extent of the relationship between intrapreneurship and company growth, multiple regressions analysis was employed.

Secondary Objective 1: To Identify Key Dimensions of Intrapreneurship: Factor analysis showed that intrapreneurship level in the iron and steel manufacturing companies was through $31.92 \%$ company support for innovativeness, $19.25 \%$ individual innovativeness, $18.71 \%$ individual proactiveness, and lastly $16.86 \%$ company support for risk taking. Similar to Jong et al. (2011), the four preceding intrapreneurial factors explained $86.74 \%$ of the dimensions of intrapreneurship also designated as innovativeness, proactiveness, and risk taking.

Secondary Objective 2: To Identify Key Measures of Company Growth: Financial and product range measures were subjected to a principal component analysis to test their significance in measuring company growth. The factor analysis confirmed that company growth is linked to financial and product range measures. Similar to what was proposed by Zhou \& de Wit (2009), the construct of financial measures identified in this study is made up of a combination of increases in sales, market share, and profits. Company growth was previously ascribed to product range and new product introductions in studies by Gerald \& Elisifa (2013) and Cucculelli \& Ermini (2012) respectively. Measures of company growth were attributable to $42.48 \%$ financial and $27.21 \%$ product range. Financial and product range measures explained $69.69 \%$ of the measures of company growth.

Secondary Objective 3: To find out if there is a significant relationship between intrapreneurship and the growth of iron and steel manufacturing companies in Bulawayo, Zimbabwe. The Pearson Correlation test was used to find out the level of significance between intrapreneurship and company growth. Table 1 shows the Pearson correlations.

Table 1: Pearson (r) Correlations N=89

\begin{tabular}{|c|c|c|c|c|c|}
\hline & 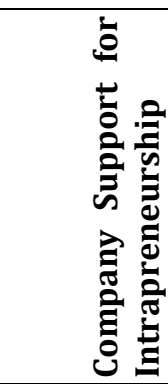 & 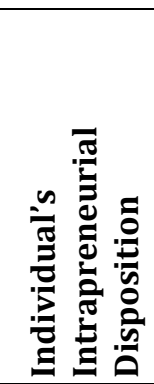 & 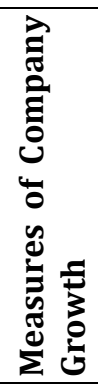 & 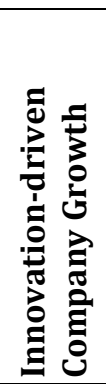 & 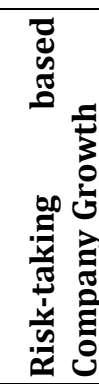 \\
\hline Company Support for Intrapreneurship (CSI) & 1 & & & & \\
\hline Individual's Intrapreneurial Disposition (IID) & 0.044 & 1 & & & \\
\hline
\end{tabular}




\begin{tabular}{lllllll}
\hline Measures of Company Growth & 0.177 & $0.547^{* *}$ & 1 & & \\
Innovation-driven Company Growth & 0.178 & $0.260^{*}$ & $0.437^{* *}$ & 1 & \\
Risk-taking based Company Growth & $0.304^{* *}$ & -0.009 & $0.350^{* *}$ & $0.271^{*}$ & 1 \\
\hline
\end{tabular}

${ }^{*}$ Correlation is significant at the 0.05 level (2-tailed); i.e. $p$ value less than 0.05 .

${ }^{* *}$ Correlation is significant at the 0.01 level (2-tailed); i.e. p value less than 0.01 .

Source: Primary data

A very strong correlation (Accept p-value less than 0.01) was observed on relationship between: (1) individual's intrapreneurial disposition and measurement of company growth ( $\left.\mathrm{r}=.547^{* *}\right)$; and (2) company support for intrapreneurship and risk taking based company growth $\left(\mathrm{r}=.304^{* *}\right)$. A strong correlation (Accept p-value less than 0.05) was also observed between individual's intrapreneurial disposition and innovationdriven company growth $\left(\mathrm{r}=.260^{*}\right)$. The strong relationships between intrapreneurship and company growth revealed in this study agreed with Garcia-Manjon \& Romero-Marino's (2012) tying up of company growth to introduction of innovation and technical changes. Similar studies were also done in France and Italy by Colombelli, Haned \& Le Bas (2013) and Cucculelli \& Ermini (2012) respectively to confirm that innovative companies grew more than non-innovative companies. The resultant company growth was actively measured by intrapreneurs as emphasised by Gruenwald (2015). On the other hand, deliberate company support for intrapreneurship helped the companies to grow through risk taking.

Secondary Objective 4: To find out the extent to which intrapreneurship contributes to the growth of iron and steel manufacturing companies in Bulawayo, Zimbabwe. In order to establish the extent to which intrapreneurship was related to company growth, predictor model(s) were developed using multiple regression analysis. Multiple regression was adopted because there are more than one predictor and dependent variables. Two models were developed to predict (1) innovation-driven company growth and (2) risk- taking based company growth. Table 2 shows the multiple regression model of innovation-driven company growth.

Table 2: Multiple Regression Model for Innovation-Driven Company Growth N=89

a. Predictors: (Constant), Individual's Intrapreneurial Disposition (IID)

\begin{tabular}{|c|c|c|c|c|c|c|}
\hline \multirow[b]{2}{*}{ Model } & & \multicolumn{2}{|c|}{ Unstandardized Coefficients } & \multicolumn{3}{|c|}{ Standardized Coefficients } \\
\hline & & $\mathrm{B}$ & Std. Error & Beta & $\mathrm{T}$ & Sig. \\
\hline 1 & (Constant) & 0.822 & 1.020 & & 0.805 & 0.423 \\
\hline & IID & 0.545 & 0.217 & 0.260 & 2.512 & 0.014 \\
\hline
\end{tabular}

\section{b. Dependent Variable: Innovation-driven Company Growth}

$\begin{array}{lllllll}\text { Model } & \text { R } & \text { R Square } & \text { Adjusted R Square } & \text { Std. Error of the Estimate } & \text { F } & \text { Sig. } \\ 1 & 0.260 & 0.068 & 0.057 & 1.008 & 6.311 & 0.014\end{array}$

c. Excluded Variables: Company Support for Intrapreneurship (CSI)

\begin{tabular}{lllll} 
Model & & Beta In & T & Sig. \\
1 & CSI & 0.167 & 1.625 & 0.108 \\
\hline
\end{tabular}

CSI - Company Support for Intrapreneurship

IID - Individual's Intrapreneurial Disposition

Source: Primary data

It was also noted that the statistical significance levels for individual's intrapreneurial disposition and company support for intrapreneurship were 0.014 and 0.108 respectively. Company support for intrapreneurship was rejected from model 1 (Accept a p-value below 0.05). Overall, the regression model 1 was significant at 0.014 (Accept p-value below 0.05). Although statistically significant, the level of 
contribution of individual's intrapreneurship disposition to company growth was low (Adjusted R square = 0.057). This indicated that other factors, not included in the model contributed more to company growth than individual's intrapreneurship disposition. Company support for intrapreneurship (Beta $=0.167$ ) was excluded from the model because its contribution to company growth was far lower than individual's intrapreneurship disposition (Beta $=0.260$ ). Due to the low level of contribution of individual's intrapreneurship disposition to company growth, the Confederation of Zimbabwe Industries (2018) was vindicated for pinning hope for growing the iron and steel sector together with the rest of the manufacturing sector on addressing macro-issues.

The key macro issues nominated for correction were: (1) policy inconsistencies; (2) high costs of production; (3) foreign currency shortages; (4) funding challenges; (5) antiquated equipment; (6) unstable macroeconomic environment; (7) competition from cheap imports; and (8) corruption. Further regression analysis showed that spotting opportunities that bring business to the company ahead of others was linked to company growth. However, action oriented items like starting new things and changing ideas into reality were not related to company growth. This implies that the individual employees in the surveyed companies were not voluntarily involved in performing activities that promoted company growth. This contradicted what was posited by Sarlija et al. (2016) that individuals are determinants of company growth. A second variant of company growth is driven by risk taking. Table 3 shows the regression model of risk-taking based company growth.

Table 3: Multiple Regression Model for Risk-Taking Based Company Growth N=89

a. Predictors: (Constant), Company Support for Intrapreneurship (CSI)

\begin{tabular}{lllllll}
\hline \multicolumn{2}{c}{ Unstandardized Coefficients } & Standardized Coefficients & & \\
Model & B & Std. Error & Beta & T & Sig. \\
2 & (Constant) & 1.463 & .348 & & 4.203 & 0.000 \\
& CSI & 0.262 & 0.088 & 0.304 & 2.977 & 0.004
\end{tabular}

b. Dependent Variable: Risk-taking based Company Growth

$\begin{array}{lllllll}\text { Model } & \text { R } & \text { R Square } & \text { Adjusted R Square } & \text { Std. Error of the Estimate } & \text { F } & \text { Sig. } \\ 2 & 0.304 & 0.092 & 0.082 & 0.752 & 8.862 & 0.004\end{array}$

c. Excluded Variables: Individual's Intrapreneurial Disposition (IID)

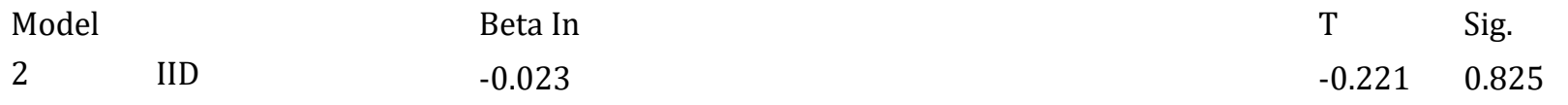

CSI - Company Support for Intrapreneurship

IID - Individual's Intrapreneurial Disposition

Source: Primary data

The statistical significance levels for individual's intrapreneurial disposition and company support for intrapreneurship to risk-based company growth were 0.825 and 0.004 respectively. Individual's intrapreneurial disposition was rejected from model 2 (Accept p-value below 0.05). Overall, the regression model 2 was significant (Accept p-value below 0.01). This study confirmed results of similar studies done in Dutch (Zhou \& de Wit, 2009) and Indian (Seshadri \& Tripathy, 2006) companies, which stated that it was difficult to shift employees from an 'employee mind-set' to an 'intrapreneur mind-set' as a driver for company growth. Company support for intrapreneurship showed potential to improve company growth by $8.2 \%$ (Adjusted R square $=0.082$ ). The low level of contribution of company support for intrapreneurship to risktaking based company growth (Adjusted R square $=0.082$ ) indicated that other factors, not included in the model contributed more to company growth than the chosen variable. 
Individual's intrapreneurial disposition (Beta $=-0.023$ ) was excluded from the model because its contribution to company growth was negative and far lower than contribution of company support for intrapreneurship $($ Beta $=0.304)$. Further regression analysis showed that allowing employees to take risks in their jobs contributed to the risk-taking based company growth. However, the surveyed companies did not fully support intrapreneurship as a key driver of company growth. Respondents revealed that their employing companies did not freely allow them to introduce new ideas and to use company resources to try new business ideas. This contradicted Alipour, Idris \& Karimi (2011) who posited that management support is at the core of facilitating intrapreneurship by availing adequate resources and ensuring that there is buy-in into intrapreneurial initiatives throughout the company.

Qualitative Data Presentation and Analysis: Qualitative data was translated from its raw state into findings by cyclically: (1) transcribing raw data; (2) organising and preparing data for analysis; (3) thoroughly reading the data; (4) computer coding the data; (5) deducing themes; and interpreting themes. Qualitative data was coded and analysed using the QSR NVIVO 10 package. The focus was on "what is said" more than "how it is said" and hence thematic analysis was used to uncover patterns from the collected data (Ragab \& Arisha, 2018). Thematic analysis of the qualitative data yielded results in maps, charts, and figures. Similar to Creswell's (2014) approach, qualitative data analysis was done parallel to data collection to focus only on valuable data and disregard unwanted data. For example, in the castables and foundry stratum, the second respondent was chosen to put more perspectives on what the researcher had inferred from the first interviewee's answers. Figure 2 shows a tree map of the key themes derived from the participants' answers.

\section{Figure 2: Key Themes Derived from Participant Answers}

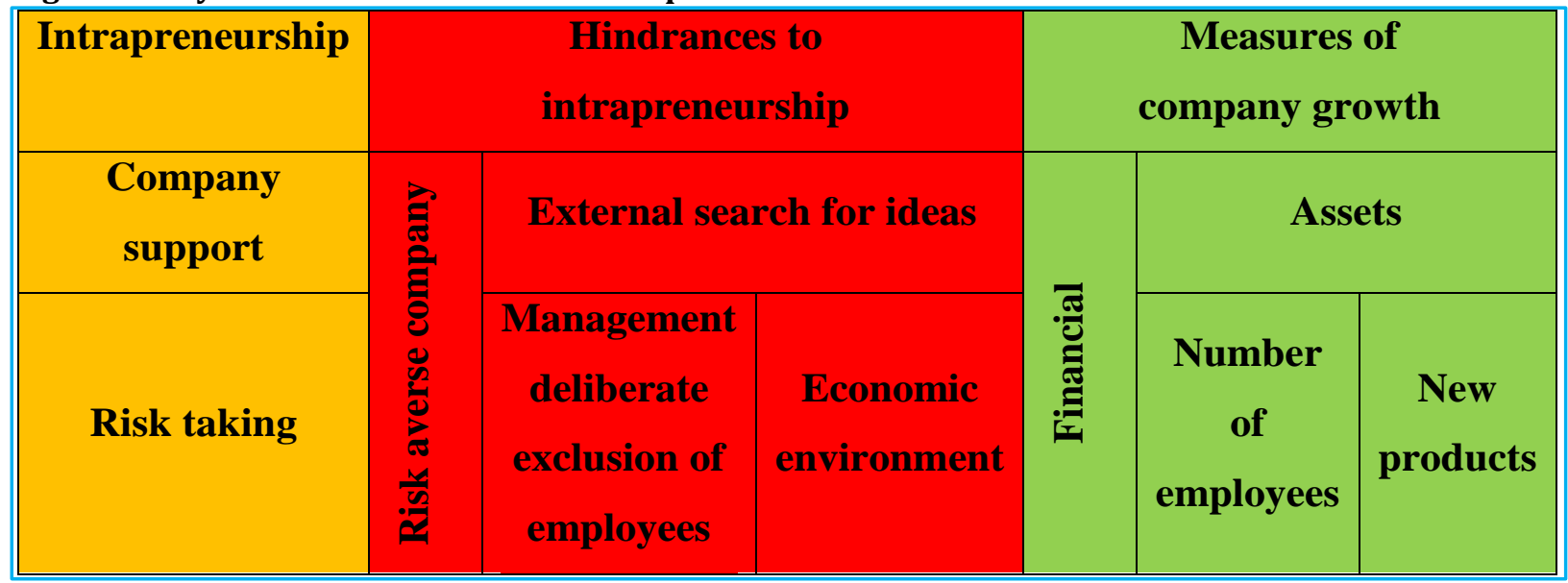

Source: Thematic analysis of primary data

Company growth, hindrances to intrapreneurship, and intrapreneurship were emphasised by participants in receding order. This trend showed that company growth was well understood while intrapreneurship as a concept had not yet fully permeated the iron and steel manufacturing companies in Bulawayo, Zimbabwe.

Secondary Objective 1: To Identify Key Dimensions of Intrapreneurship: Intrapreneurship was mainly interrogated in the interviews by checking on company support for innovation and permission to take risks by company's employees. All the participants emphasised the need to identify, assess, control, manage, eliminate, and minimise risks. Specifically, a number of participants highlighted a need to "avoid creating risks," "insure against risks," "mitigate the risks," "adhere to procedures and standards," "train employees," and "forbid risk taking." Company support for new ideas was mentioned by all participants with the exception of participant ISK07. However, generation of ideas was largely outsourced as noted by all participants, except ISK03 and ISK07. At individual level, it was interesting to note that no participant volunteered any record of breakthrough ideas that they contributed to their companies. Employee involvement in idea generation was promoted in the iron and steel manufacturing companies in Bulawayo through allowing for (1) brainstorming, [2] putting suggestion boxes, (3) promoting research, and (4) employee debates. 
However, companies favoured input from non-employee sources like magazines, management meetings, and exhibitions. Management's exclusion of employee involvement under the guise of managing risk was exposed by participant ISK06 who said, "Management go for strategic retreats..." and also: "The company does not tolerate deliberate exposure to risky activities caused by employees as it believes that not everyone is empowered to take risks on behalf of the company. Choosing risky activities to pursue is a strategic level matter for which employees have no direct role to play. Instead, company employees are continually trained on how to prevent risks or minimise them if they are to occur." On the flip side, participant ISK03 said, "I think as an organisation, to succeed, we should take risks. Most of the times we have managed to be successful through risk taking and this has enabled us to grow. It is through risk taking for us to generate new ideas which are essential to the organisation."

Azami (2013) highlighted that the focus of intrapreneurship is on innovation and risky activities. Furthermore, Birkemalm \& Jansson (2018) noted that intrapreneurship is motivated by challenges and accomplishment for which risk is shared with the employing company. This study showed that innovation and risk taking were not popular in the iron and steel companies in Bulawayo. All the focus was directed at research and development department and meetings to take the companies forward.

Secondary Objective 2: To Identify Key Measures of Company Growth: Company growth, as picked from participants' answers, was determined primarily by financial measures like sales revenues, profits, and market share. Company growth was also measured by products number or range, and assets held by the company. With the exception of three participants, namely; ISK01, ISK04, and ISK06, all the other five participants mentioned products as a measure of company growth. Similarly, six participants mentioned number of employees as a measure of company growth. Measurement of company growth has no universally acceptable formula with business practitioners and academics separately advocating for qualitative and quantitative measures respectively (Gruenwald, 2015). This study disagreed with the assertion by Gruenwald (2015) as the measures of company growth were all inclined towards quantitative measures such as financial measures, number of employees, productivity, assets held, and product range.

Secondary Objective 3: To find out if there is a significant relationship between intrapreneurship and the growth of iron and steel manufacturing companies in Bulawayo, Zimbabwe. The significance of the relationship between intrapreneurship and company growth was gauged by the prominence given to each variable or its subsidiary elements. Figure 3 shows the words mentioned most by the participants.

Figure 3: Word Tree Map on Role of Intrapreneurship on Company Growth

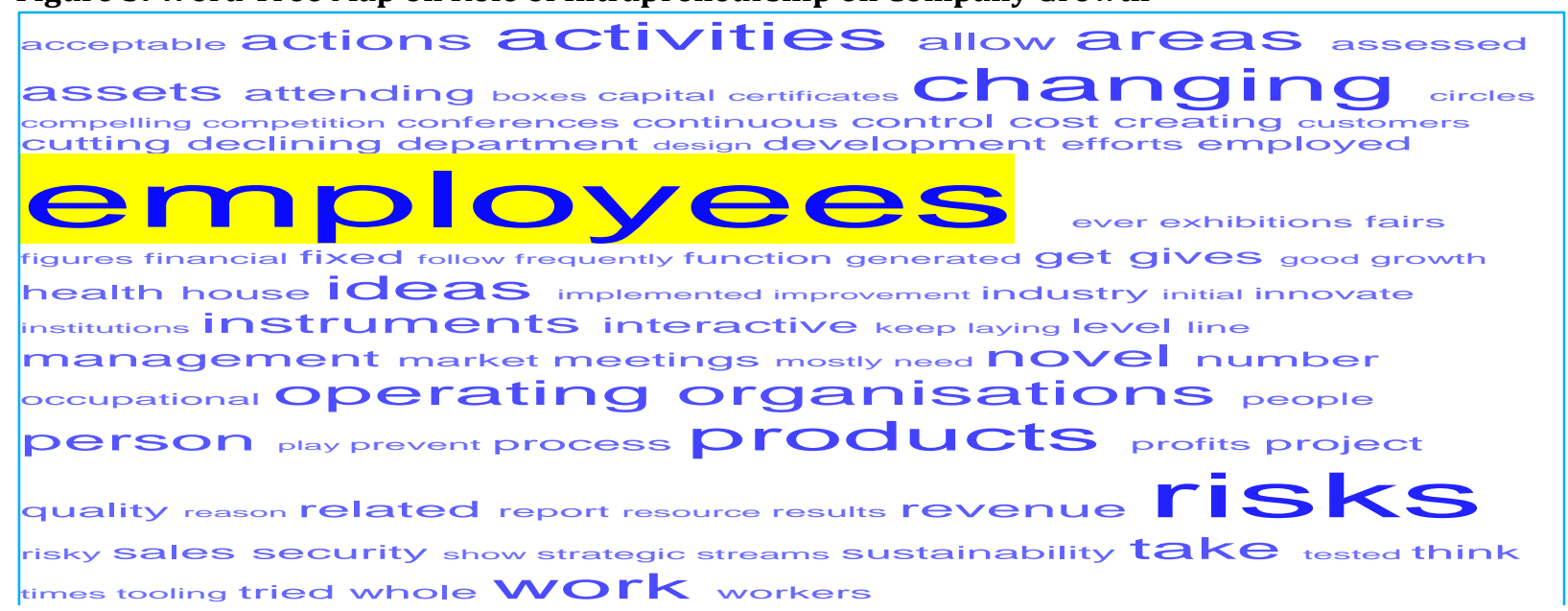

Source: Primary data

All participants built their answers around "employees" or "person," making employees the most prominent word. "Risks" and "changing" followed as the next most popular words. Prominence was also given to "products," "work," and "ideas." From the word tree map, employees formed the core of the link between intrapreneurship and company growth. Garcia-Manjon \& Romero-Marino (2012) linked innovation to 
company growth. We have no room for trial and error. We also tap a lot into agricultural research institutions and in-house we rely mostly on our research and development department to lead the search for new improvement initiatives. This explains why the word "employees" was the most mentioned word by the participants. Employees link novel ideas to the growth of the company through taking risk at times.

Secondary Objective 4: To find out the extent to which intrapreneurship contributes to the growth of iron and steel manufacturing companies in Bulawayo, Zimbabwe: The extent to which intrapreneurship affects the growth of iron and steel manufacturing companies in Bulawayo was best assessed by checking if participant answers tied up the dimensions of intrapreneurship to the measures of company growth. Figure 4 shows the cluster analysis chart for the participant answers.

Figure 4: Nodes Clustered by Coding Similarity

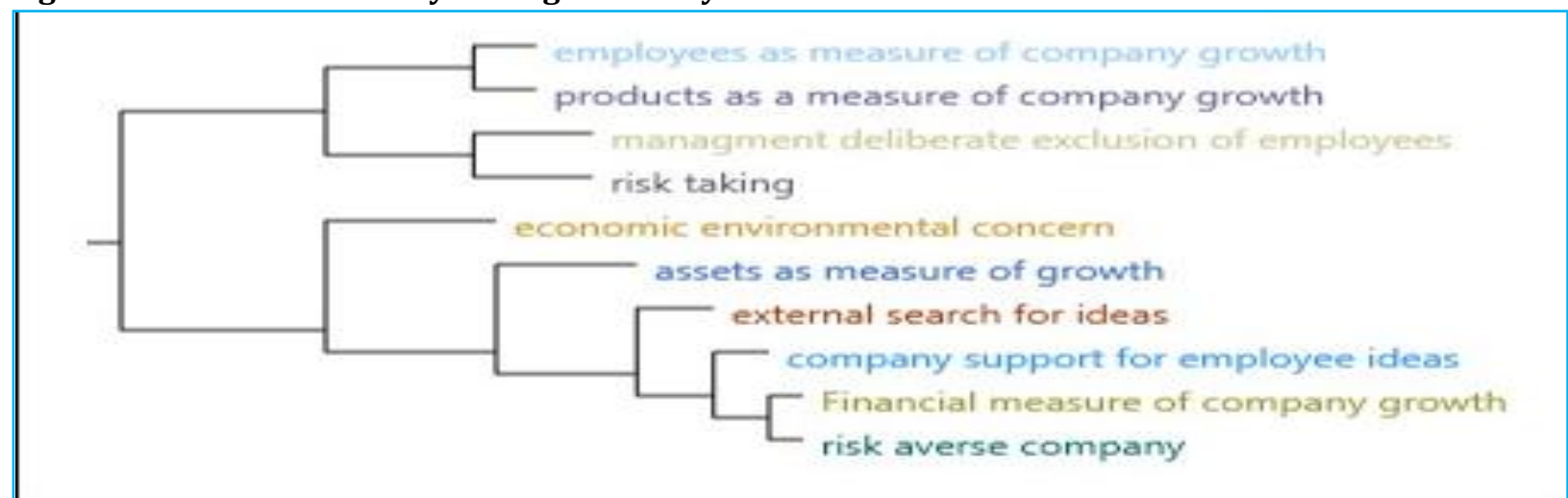

Source: Primary data

Financial measures of company growth and risk averseness were mentioned by all participants. The more companies thought about financial growth of the company, the more they were likely not to allow their employees to take risks. New ideas and taking risks were observed to lead to growth of companies. The relationship between intrapreneurship and company growth can be decomposed to show the relationship between: (1) new ideas and company growth, and (2) risk taking and company growth as shown in Figures 5 and 6 respectively.

Figure 5: New Ideas and Company Growth

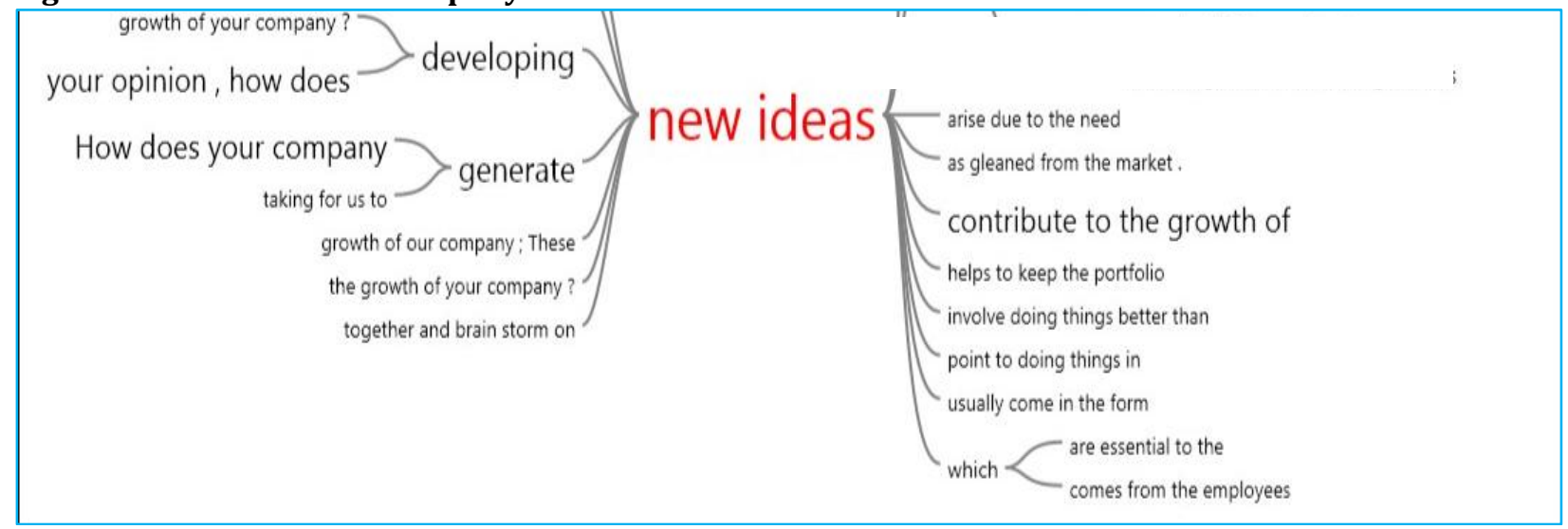

Source: Primary data

A strong relationship was deemed to exist between new ideas and company growth. Company growth was ascribed to doing things better. 


\section{Figure 6: Risk Taking and Company Growth}

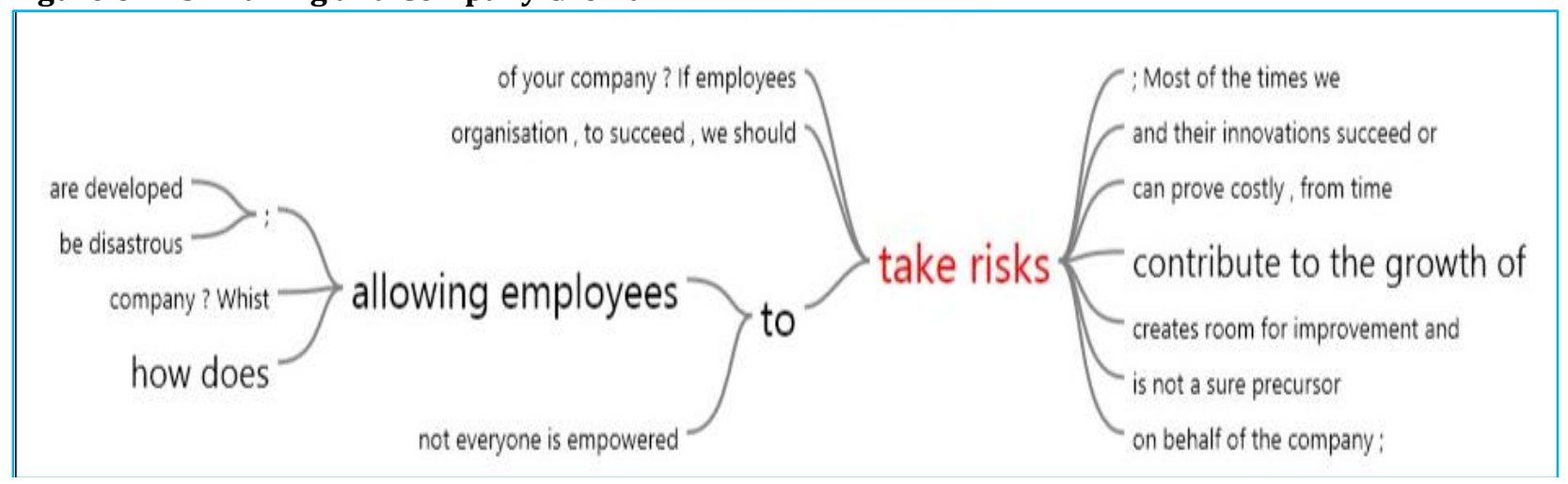

Source: Primary data

Although risk taking was not favoured by the interviewed participants, all the participants concurred that risk taking, if successful, contributed to company growth. However, there were attempts by the participants to blame the operating environment for the general risk aversion in the iron and steel manufacturing companies. Participant ISK08 mentioned the environment three times in responding to various questions. The approach taken by participant ISK08 was a deliberate move to put the answers in the context of existing economic environment and in the process justify the lack of risk taking in employing company. Firstly, participant ISK08 said: "The environment we are operating in does not allow the company to give employees freedom to experiment with scarce resources. Only if there is a compelling reason, do we allow experimentation, but only with tried, tested, and proven ideas. Of course once in a while we get brilliant ideas from our employees, which we adopt." Secondly, participant ISK08 said: "The environment we are operating in is inflationary..." Thirdly, participant ISK08 said: "However, in the current environment we do not have the luxury to risk company resources. What we have noted is that employees need incentives to excite them to innovate within the allowed limits."

\section{Conclusion and Policy Recommendations}

The study drew the following conclusions. Overall, intrapreneurship was not a preferred strategy for driving growth in the iron and steel manufacturing companies in Bulawayo. Financial and product range were identified as the key measures of company growth. Company support for intrapreneurship and individual's intrapreneurial disposition were statistically linked to company growth. Quantitatively and qualitatively, identification of opportunities by individuals and allowing employees to take risks in their jobs were credited for marginally driving company growth by $5.7 \%$ and $8.2 \%$ respectively. However, the free flow of ideas and risk taking by employees were inhibited in the iron and steel manufacturing companies in Bulawayo, Zimbabwe.

Based on the findings and conclusions discussed in the previous section, recommendations for this study are summarised as follows:

- If intrapreneurship is to be pursued as a long term strategy for company growth, serious promotion of innovativeness, proactiveness, and risk taking is needed.

- In addition to quantitative measurement of growth in the studied companies, qualitative measurement should also be utilised to get a full picture of company growth.

- Employees should be motivated and supported to intrapreneurially drive the growth of iron and steel manufacturing companies in Bulawayo through ideas, actions, and work.

- To increase the role of intrapreneurship on the growth of iron and steel manufacturing companies in Bulawayo, free generation and implementation of ideas, complemented by increased tolerance for risk taking by employees, should be encouraged.

Contribution of the Study to the Body of knowledge: The role of intrapreneurship on the growth of companies was widely studied in developed and emerging countries. However, little was published in 
developing countries in general, and more specifically in Zimbabwe. Confederation of Zimbabwe Industries (2009 - 2018) repeatedly presented drastic policy shifts, high costs of production, foreign currency shortages, lack of concessionary funding, aged equipment, unstable macroeconomic environment, competition from cheap imports, and corruption as the causative factors for the poor performance of the manufacturing sector in Zimbabwe. However, this study established that intrapreneurship was a missing element that could, in a way, buttress various ongoing efforts to grow the iron and steel manufacturing companies in Bulawayo, Zimbabwe.

Areas for Further Research: Further studies could be conducted on why iron and steel employees lacked intrapreneurial enthusiasm to act on their ideas and the reasons for low company support for risk taking employees.

\section{References}

Alipour, F., Idris, K. \& Karimi, R. (2011). Intrapreneurship in Learning Organizations: Moderating Role of Organizational Factors. Journal of American Science, 7(11), 141-150.

Antoncic, B. \& Hisrich, R. D. (2003). Clarifying the intrapreneurship concept. Journal of Small Business and Enterprise Development, 10(1), 7-24.

Atheya, R. \& Arora, R. (2015). Augmenting Intrapreneurship in Learning Organisations. Advances in Economics and Business Management (AEBM), 2(12), 1165-1168. Krishi Sanskriti Publications.

Azami, S. (2014). Entrepreneurs necessitate Intrapreneurs to foster their organisation. International Journal of Advancement in Engineering Technology, Management \& Applied Science, 1(7), 21-30.

Azami, S. (2013). Intrapreneurship - An Exigent Employment. International Journal of Scientific \& Technology Research, 2(4), 194-198.

Birkemalm, P. \& Jansson, S. (2018). Entrepreneurs versus Intrapreneurs: A comparative study about motivation factors of entrepreneurs and intrapreneurs. Dissertation of the Umea School of Business and Statistics.

Bryman, A., Bell, E., Hirschsohn, P., Dos Santos, A., du Toit, J., Masenge, A., Van Aardt, I. \& Wagner, C. (2017). Research Methodology: Business and Management Contexts, Oxford University Press. Southern Africa.

Buekens, W. (2014). Fostering Intrapreneurship: The challenge for a New Game Leadership. 21st International Economic Conference, Sibiu, Romania. Procedia Economics and Finance.

Cameron, R. (2015). Mixed Methods Research. Mixed Methods Research Workshop, Deakin University, Melbourne.

Colombelli, A., Haned, N. \& Le Bas, C. (2013). On firm growth and innovation: Some new empirical perspectives using French CIS. Structural Change and Economic Dynamics, 26, 14-26.

Confederation of Zimbabwe Industries. (2009-2018). Manufacturing Sector Survey.

Creswell, J. W. (2014). Research design: qualitative, quantitative, and mixed methods approaches (4th ed.), Publications, Inc.

Cucculelli, M. \& Ermini, B. (2012). New product introduction and product tenure: What effects on firm growth? Research Policy, 41, 808-821.

De Jong, J. \& Wennekers, S. (2008). Intrapreneurship: Conceptualizing entrepreneurial employee behaviour in Netherlands. EIM, 1-47.

Deloitte. (2015). Five Insights into Intrapreneurship: A Guide to Accelerating Innovation within Corporations. Deloitte Digital.

Deloitte. (2017). Overview of Steel and Iron Market. Global Steel and Iron Market, 1-25.

Dikko, M. (2016). Establishing Construct Validity and Reliability: Pilot Testing of a Qualitative Interview for Research in Takaful (Islamic Insurance). The Qualitative Report, 21(3), 521-528.

Dube, C. (2011). Positioning Zimbabwe Manufacturing Sector as a growth driver: Lessons from Singapore and Taiwan. ZEPARU Working Paper Series (ZWPS 4/11). Zimbabwe Economic Policy Analysis and Research Unit (ZEPARU). Engineering, Iron and Steel Association of Zimbabwe (EISAZ). [Online]. Accessed 15/05/2019.

Garcia-Manjon, J. V. \& Romero-Marino, M. E. (2012). Research, development and firm growth. Empirical evidence from top R\&D spending firms. Research Policy, 41, 1084-1092. 
Gerald, A. \& Elisifa, N. (2013). Analysis of business growth and their contribution to business growth: A Tanzania Case Study. International Journal of Economics, Commerce and Management, 1(1).

Gonzalez, I. H. \& Kaminski, J. (2011). The iron and steel industry: a global market perspective. Gospodarka Surowcami Mineralnymi, 5-28.

Greener, S. (2008). Business research methods. Frederiksberg: Ventus Publishing ApS.

Gruenwald, R. K. (2015). Measuring growth of the firm: Theoretical considerations. In: A. Glodowaska (Eds). International Business and global economy, 1(2), 121-131.

Jong, J. P. J., Parker, S. K., Wennekers, S. \& Wu, C. (2011). Corporate Entrepreneurship at the Individual Level: Measurement and Determinants. Working Paper, 1-27. March 2011.

Kothari, C. R. (2004). Research Methodology: Methods and Techniques (2 ${ }^{\text {nd }}$ ed.), New Age International Publishers, India.

Lee, N., Brown, R. \& Schlueter, T. (2016). Modes of firm growth. ERC Research Paper, 46, 1-54.

Lockett, A., Wiklund, J., Davidsson, P. \& Girma, S. (2011). Organic and Acquisitive Growth: Re-examining Testing and extending Penrose's Growth Theory. Journal of Management Studies, 48(1), 48-74.

Maier, V. \& Zenovia, C. P. (2011). Entrepreneurship versus Intrapreneurship. Review of International Comparative Management, 12(5), 971-976.

Matinde, E. (2014). Assessment of the Technological and Innovation Capabilities in the Iron and Steel Sector in Zimbabwe; Imperatives towards Developing and Innovation-Driven Beneficiation Framework. Dissertation of the University of Zimbabwe.

Mbira, L. (2015). The de-industrialization of Bulawayo manufacturing sector in Zimbabwe: Is the capital vacuum to blame? International Journal of Economics, Commerce and Management, 3(3), 1-15.

Ministry of Finance. (2018). Transitional Stabilization Programme (TSP) - Reforms Agenda (October 2018 December 2020). Government of Zimbabwe.

Ministry of Finance. (2013). Zimbabwe Agenda for Sustainable Socio-Economic Transformation (Zim ASSET) (October 2013 - December 2018). Government of Zimbabwe.

Mlambo, A. S. (2017). From an Industrial Powerhouse to a Nation of Vendors: Over Two Decades of Economic Decline and Deindustrialization in Zimbabwe 1990-2015. Journal of Developing Societies, 33(1), 99125.

Mudarikiri, G. (2012). Banks fail to disburse US\$44m ZETREF funds. Zimbabwe Independent, 27 July 2012.

Nicolaidis, C. S. \& Kosta, G. C. (2011). Intrapreneurship as a Unique Competitive Advantage. Journal of World Academy of Science, Engineering and Technology, 1121-1125.

Ogidi, A. E. (2014). Intrapreneurship and Corporate Innovation. SCSR Journal of Management and Marketing (SCSR-JMM), 1(1), 19-32.

Pal, S. (2013). A study on the performance and prospect of Indian steel industry from national perspective under globalisation. International Journal of Economics, Commerce, and Research (IJECR), 3(3), 53-60.

Pickford, H. C. \& Joy, G. (2016). Organisational Citizen Behaviours: Definitions and Dimensions. Said Business School Research Papers. University of Oxford.

Pindiriri, C. (2018). The Engineering Sector in Zimbabwe: A survey of the sector. National Employment Council for the Engineering, Iron and Steel Industry, 1-19.

Ragab, M. A. F. \& Amr Arisha, A. (2018). Research Methodology in Business: A Starter's Guide. Journal of Management and Organizational Studies, 5(1), 1-14.

Raosoft Sample Size Calculator. (2004). Raosoft Inc. [Online]. Accessed 01/05/2019.

Ryan, A. B. (2006). Post -Positivist Approaches to Research (Unpublished), 12-26.

Samukange, T. (2015). Government, Old Mutual working on DIMAF II. Newsday, 2 July 2015.

Sarlija, N., Pfeifer, S., Jeger, M. \& Bilandzic, A. (2016). Measuring Enterprise Growth: Pitfalls and Implications. International Journal of Social, Behavioural, Educational, Economic, Business and Industrial Engineering, 10(6), 1781-1788.

Saunders, M., Lewis, P. \& Thornhill, A. (2016). Research Methods for Business Students (7th ed.), England, Pearson Education Limited.

Sekaran, U. (2003). Research Methods for Business: A Skill Building Approach (4th ed.), New York, John Wiley $\&$ Son, Inc.

Seshadri, D. V. R. \& Tripathy, A. (2006). Innovation through Intrapreneurship: The Road Less Travelled. Vikalpa, 31(1), 17-29.

Singal, A. (2018). An Analysis of the Impact of Imports of Steel from China on Indian Steel Industry. Journal of Business \& Financial Affairs, 7(2), 1-7. 


\section{Journal of Economics and Behavioral Studies (ISSN: 2220-6140)}

Vol. 12, No. 1, pp. 22-37, February 2020

Stefanovici, S. (2012). Intrapreneurship - a review of recent literature. Unpublished.

Stoneman, C. (1990). The Industrialisation of Zimbabwe-Past, Present and Future. Afrika Focus, 3(4), 242282.

Tajnikar, M., Ponikvar, N. \& Bonca, P. D. (2016). Characteristics of firms with different types of growth: the case of Slovenia. Economic Annals, 23(208), 27-47.

Taylor, S. J., Bogdan, R. \& DeVault, M. L. (2016). Introduction to Qualitative Research Methods: A Guidebook and Resource ( $4^{\text {th }}$ ed), John Wiley \& Sons, Inc. Hoboken, New Jersey.

Teddlie, C. \& Tashakkori, A. (2006). A General Typology of Research Designs Featuring Mixed Methods. Research in the Schools, 13(1), 12-28. Mid-South Educational Research Association.

Wennekers, S. (2008). Intrapreneurship; Conceptualizing Entrepreneurial Employee Behaviour.

Zhao, L. L. (2013). Corporate Intrapreneurship: Steps to building a sustainable start-up mentality within an established organisation. Dissertation of the Massachusetts Institute of Technology.

Zhou, H. \& de Wit, G. (2009). Determinants and dimensions of firm growth. Scientific Analysis of Entrepreneurship and SMEs (SCALES), 1-34. EIM Research Reports.

Zimbabwe Economic Policy Analysis and Research Unit. (2014). Engineering and metals industry value chain analysis. ZEPARU Occasional Paper No. 02/14.

Zimbabwe Economic Policy Analysis and Research Unit (ZEPARU). (2014). Engineering and Metals Industry Value Chain Analysis. ZEPARU Occasional Paper No. 02/14. March 2014. 